\title{
Religion and the Pandemic_-Latin American Responses
}

\author{
Frank Usarski ${ }^{1} \cdot$ Fábio $\mathrm{Py}^{2}$ \\ Published online: 24 November 2020 \\ (C) The Author(s), under exclusive licence to Springer Nature Switzerland AG part of Springer Nature 2020
}

The rapid global spread of the coronavirus in the last months has caused massive effects and reactions in all spheres of life including in the field of science where researchers of different disciplines are challenged to contribute from their specific disciplinary angel to solutions of the problems directly or indirectly associated with the pandemic. Since the true extend of the COVID crises has become clear, countless scientific essays, articles, and books have taken up virtually any aspect of the subject. With the present issue, the International Journal of Latin American Religions participates in this discussion - albeit with some delay due to its semiannual publication schedule (June and December) - and the expressive number of thirteen thematically relevant articles indicates both the pandemic's severeness and intellectual potential for scholars of religion whose majority lives and works in a region which is among the hardest hit by the corona crisis.

The immediacy and impact of the current pandemic, however, must not distract us from recognizing that we are facing a particular expression of a constituent pattern of world history. Surveys indicate a steep rise of natural hazards during the twentieth century followed by an even more expressive increase at the beginning of the twentyfirst century (Gaillard and Texier 2010: 81). While it is an exaggeration to confirm that "on average, a disaster occurs somewhere in the world each day," it is fair to say that due to global media coverage, we are aware of the frequency of threatening occurrences such as "a flood, hurricane, or earthquake, a nuclear, industrial, or transportation accident, a shooting spree, or peacetime terrorist attack" (Noris et al. 2002: 207).

Frank Usarski

drusarski@gmail.com

Fábio Py

pymurta@gmail.com

1 Pontifícia Universidade Católica de São Paulo, Rua Monte Alegre, 984, São Paulo, SP 05014-901, Brazil

2 Universidade Estadual do Norte Fluminense Darcy Ribeiro, Av. Alberto Lamego, 2000, Campos dos Goytacazes, RJ 28013-602, Brazil 
In response to the regularity of calamities in affected parts of the earth, research of problems, challenges, and reactions caused by catastrophes and disasters in general and the role of religion in this context has become a flourishing field of studies long before the outbreak of the corona crises (Sanches et al. 2020).

Among cultural anthropologists and scholars of religion, it has been known long enough (Dynes and Yutzey 1965) that narratives of catastrophes and "prophecies of disaster" (Hiltebeitel 2011:273) are frequent motives of religious worldviews (Das 2006: 61). One obvious example is the biblical flood story and its imaginary "of the collapse of the ordered and predictable world, typified as chaos" (Dynes 1998: 5). Exegetes tell us that these tales of dramatic events are not considered ultimate. Rather these occurrences are constructed to prefigure an auspicious future in which everything is again in order. Similar is true for the Hindu idea of the four eras including the "dark" Kali Yuga that at his end will give rise to a new golden age and the cosmogenic concept of four periods imagined by Quechua-speaking pre-Columbian indigenous people associated with the term Pachacuti, probably coined in the face of earthquakes and other hazards and roughly translatable as "world or time reversal" (Oliver-Smith 1999:80). This "classical" emic topic is predestined to come to the fore in collectively critical moments, and as soon as the narrative is reinforced, it reveals its ambivalent character of threat and concern, on the one hand, and promise and expectation, on the other. That is why catastrophes may generate favorable conditions for the upsurge of millenarist religious movements (Barkun 1974). For the same reason, one finds on the current book market Christian reflections on the coronavirus and its aftermath under the heading God and the Pandemic (Wright 2020) as well as solacing contemplations on "the only comfort in life and death" for those who have "faith and hope" in the times of the pandemic (Lamb et al. 2020).

Since its gradual establishment as a thematically comprehensive field of study in the context of the Social Sciences from the 1970s onwards, disaster research has repeatedly shown an interest in the role and meaning of religions in the context of calamities and natural hazards. Scientists interested in related issues share the understanding that disasters are - at least to a certain extent-human-induced massive disturbances of social order that override habitual patterns of action and organization and place an excessive burden on the affected individuals and collectives (Ratt 2018:231). Under these subjectively highly stressful conditions in material, administrative and mental terms the given society is challenged to renormalize its routines. In this context, religion can play important functional roles, for example, through their organizational bodies, as a means of ideologically coping with contingency or as an ethical source for empathy and solidarity with the victims (Koenig 2006). This is certainly not always the case. Not all denominations are "green," but sometimes overtly hostile towards environmentalism according to their "climate change denial that foresees a cataclysmic end as one not man made but rather theologically bound to a god made crises" (Ronan 2017:10).

In recent years, several natural disasters such as a series of calamities in Indonesia (Call 2012) or Korea (Ha 2015), Hurricane Mitch in 1998 in Central American countries (Schipper 2010) including Honduras (Ensor 2003), the 2004 Tsunami in Thailand (Merli 2005) and Samoa (Holmgaard 2019), the Katrina Disaster in New Orleans and the American Gulf Coast in 2005 (Wessinger 2012), or the earthquake in the Sumatran city of Padang city in 2009 (Gianisa and Le De 2018) have provided concrete occasions for the research of the relation between disasters and religion. 
Many of these and other studies are guided by the question to what extent and how and why calamities may have an impact on belief systems, its followers, or its organizational preferences. A frequent topic in this context is that of "religious coping," i.e., the faculty of religion of dealing with and recovering from disasters (Park 2016). The findings of a statistically positive correlation between the subjective religiosity and a less desperate attitude towards an earthquake (Bentzen 2019) fall into this category and remind us that religion can be an important determinator of a population's vulnerability to natural hazards (Schipper 2010). One aspect in this context is the rhetorical repertoire that can be applied to calamities so that the latter become plausible according to the religion's worldview (McGeehan and Baker 2017). This is a common capacity in the world of religions indicated in statements of representatives of Shamanism, Christian, Judaism, Islam, Hinduism, Taoism and Confucianism, Shintoism, and Buddhism (Victoria 2013) and, for example, confirmed by a study of a Muslim community in Southern Thailand which associated the Tsunami to apocalyptical verses of the Quran (Merli 2005). These official interpretations do not automatically soothe a believer and can even let to a loss of faith, especially when the narrative contains a punitive theodicy and the community member does not accept the argument that a disaster has been imposed by a divine being for a higher reason and the painful calamity will ultimately turn out to be a blessing (Wessinger 2012). On the other hand, challenges of a religious plausibility by a disaster can also stimulate a religion to adopt the doctrines to the new situation (Holmgaard 2019). On the organizational level, a disaster can modify aspects such as the routine and administrative patterns of a local religious community, for example, when a community includes a remembrance event into its agenda (Eyre 2007) or improves its strategies for a more successful management of possible future calamities (Ha 2015).

The thirteen articles on the COVID crises selected for the thematic session of the present issue contribute from different angels to the discussion on the relation between religion and disasters. The first paper "Reactions to the pandemic in Latin America and Brazil: are religions essential services?" submitted by Olívia Bandeira and Brenda Carranza argues that in comparison with the situation in other Latin American countries, Brazil is not only witnessing the worst COVID scenario but also stands out for the accentuated reference to religion in public statements on the COVID crises.

The next article written by Kate Kingsbury and Andrew Chesnut discusses the role of devotional practices associated with the Mexican female folk-Saint Santa Muerte in times of the pandemic. Diego Meza calls our attention to Southwestern Colombia, or more specifically, to the religious impact of the COVID-pandemic on the population of the predominantly Catholic region of Nariño. Under a similar perspective, the fourth paper submitted by Rodrigo Serrão and João Chaves turns to three Brazilian diaspora denominations in Florida and their reaction to the COVID crises reflected by the institutions' messages in form of YouTube videos and Facebook posts. The relation between the COVID crises and social media reappears in the Giovanna Capponi's and Patrícia Carneiro Araújo's paper, this time, however, in the sense of a dependent analytical variable according to the article's leading hypothesis that the restrictions imposed by the pandemic on the communitarian life of Afro-Brazilian religions and neo-Pentecostal churches are being compensated by the use of digital means of communication. As the metaphoric title "Catholicovid-19 or Quo Vadis Catholica Ecclesia" indicates, the article of Emerson S. Silveira deals with the positions of 
Catholic circles towards the pandemic as soon as the severity of the crises became evident.

The seventh article elaborated by of Brian Gordon Lutalo Kibuuka addresses the intellectually instigating and due to its political implications controversial issue of the stances of evangelical churches on the COVID virus. The author draws parallels between the negationist attitudes of Brazilian Pentecostal churches and of Jair M. Bolsonaro towards the multifold problems caused by the COVID crises. Further reflections of the problematic role of Brazil's polemical president during the pandemic are added by Fábio Py whose harsh critics of Bolonaro's strategical misbehavior is inspired by Dorothee Sölle's concept of Christofascism. Nelson Lellis and Roberto Dutra Junior sing from a similar song-sheet while associating the counterproductive crisis management of the Bolsonaro administration with elements of evangelical faith.

The tenth paper, submitted by Renata Siuda-Ambroziak and Joana Bahia, focusses on Marcelo Crivella, mayor of the city of Rio de Janeiro and at the same time member of the higher ranks of the clergy of one of Brazil's preeminent Pentecostal denominations, the Universal Church of the Kingdom of God. This twofold commitment makes Crivella a living example for the dubious liaison of politics and religion and its "unholy" consequences for the pandemic. Siuda-Ambroziak's and Bahia's article can be read against the background of Glair Arruda's survey of the opinions of representatives of local Brazilian Christian communities about the COVID crises and its socioeconomic repercussions.

The twelfth essay is written from the perspective of material culture. The corresponding author, Patrícia Souza, contemplates on the emergence of protection masks decorated with religious motifs that make the religious confession of their wearers visible. The final paper on the COVID-19 pandemic and the ongoing genocide of black and indigenous peoples in Brazil is in a tragic sense a counterpart to Souza's reflection on a "ludic" side of the phenomenon. The article written by Raimundo C. Barreto closes the thematic session to underline the true drama of the current crises. We wish that the selected articles are read in this spirit and strengthen our sense for solidarity and responsibility in an extraordinary and difficult period of our lives.

\section{References}

Barkun M (1974) Disaster and the millennium. Yale University Press, New Haven

Bentzen JS (2019) Acts of God? Religiosity and natural disasters across subnational world districts. Econ J 129:2295-2321

Call CM (2012) Viewing a world of disaster through the eyes of faith: the influence of religious worldviews on community adaptation in the context of disaster-related vulnerability in Indonesia. Available via DIALOG http://lib.dr.iastate.edu/etd/12289. Accessed 5 Nov 2020

Das V (2006) Life and words: violence and the descent into the ordinary. University of California Press, Berkeley

Dynes RR (1998) Noah and disaster planning: the cultural significance of the flood story. Preliminary paper no. 265. University of Delaware. Available via DIALOG DE. http://citeseerx.ist.psu.edu/viewdoc/ download?doi=10.1.1.568.5959\&rep=rep1\&type=pdf. Accessed 2 Nov 2020

Dynes R R, Yutzey D (1965) The religious interpretation of disaster. Topic 10. J Lib Arts, Fall 34-48

Ensor MO (2003) Disaster evangelism: religion as a catalyst for change in post-Mitch Honduras. Int J Mass Emerg Disasters 21:31-49

Eyre A (2007) Remembering: community commemoration after disaster. In: Rodríguez H, Quarantell EL, Russell R, Dynes RR (eds) Handbook of Disaster Research. Springer, New York, pp 442-455 
Gaillard JC, Texier P (2010) Religions, natural hazards, and disasters: an introduction. Religion 40:81-84

Gianisa A, Le De L (2018) The role of religious beliefs and practices in disaster: the case study of 2009 earthquake in Padang city, Indonesia. Disaster Prev Manag 27:74-86

Ha K-M (2015) The role of religious beliefs and institutions in disaster management: a case study. Religions 6: 1314-1329

Hiltebeitel A (2011) Dharma. Its early history in law, religion, and narrative. Oxford University press, Oxford

Holmgaard SB (2019) The role of religion in local perceptions of disasters: the case of post-tsunami religious and social change in Samoa. Environ Hazards 18:311-325

Koenig HG (2006) In the wake of disaster: religious responses to terrorism and catastrophe. Templeton Foundation, Philadelphia

Lamb J, Martinez P, Gaetano GCD (2020) The only comfort in life and death. Faith and hope in the pandemic. Christian Focus Publications, Geanies House

McGeehan KM, Baker CK (2017) Religious narratives and their implications for disaster risk reduction. Disasters 41:258-281

Merli C (2005) Religious interpretations of tsunami in Satun province, southern Thailand: reflections on ethnographic and visual materials. Sven Relig Årsskrift 14:154-181

Norris FH, Friedman MJ, Watson PJ, Byrne CM, Diaz E, Kaniasty K (2002) 60000 disaster victims speak: part I. an empirical review of the empirical literature, 1981-2001. Psychiatry 65:207-239

Oliver-Smith A (1999) Peru's five-hundred-year earthquake: vulnerability in historical context. In: OliverSmith A, Hoffman SM (eds) The angry earth: disaster in anthropological perspective. Routledge, New York, pp 74-88

Park CL (2016) Meaning making in the context of disasters. J Clin Psychol 72:1234-1246

Ratt S (2018) Katastrophe. In: Schneller B, Tuma R, Lehn D, Traue B, Eberle TS (eds) Kleines Al(e)phabet des Kommunikativen Konstruktivismus. Fundus Omnium Communicativum - Hubert Knoblauch zum 60. Geburtstag. Springer VS, Wiesbaden, pp 227-233

Ronan M (2017) Religion and the environment: twenty-first century American evangelicalism and the Anthropocene. Humanities 6:1-15

Sanches MA, Lovo OA, Sanches LC (2020) Religião e epidemias na história: do essencial ao perverso. REVER - Rev Estud Relig 20:139-152. https://doi.org/10.23925/1677-1222.2020vol20i2a10

Schipper ELF (2010) Religion as an integral part of determining and reducing climate change and disaster risk: an agenda for research. In: Voss M (ed) Der Klimawandel. Sozialwissenschaftliche Perspektiven. Verlag für Sozialwissenschaften, Wiesbaden, pp 377-393

Victoria B (2013) Religious responses to natural disasters: from hurricane Katrina to the great east Japan earthquake. In: Yau S-t K (ed) Natural disaster and reconstruction in Asian economies. Palgrave Macmillan, New York, pp 51-66

Wessinger C (2012) Religious responses to the Katrina disaster in New Orleans and the American Gulf Coast. J Relig Stud 86:243-273

Wright T (2020) God and the pandemic. A Christian reflection on the coronavirus and its aftermath. Zondervan Reflective, London

Publisher's Note Springer Nature remains neutral with regard to jurisdictional claims in published maps and institutional affiliations. 